\title{
CRITICAL FACTORS INFLUENCING MOOCS RETENTION: THE MEDIATING ROLE OF INFORMATION TECHNOLOGY
}

\author{
Amin Ullah KHAN \\ ORCID: 0000-0002-2186-337X \\ Department of Economics and Law \\ University of Macerata \\ Macerata, ITALY \\ Dr. Kashif Ullah KHAN \\ ORCID: 0000-0002-0604-3103 \\ School of Management Sciences \\ Ghulam Ishaq Khan Institute of Engineering Sciences and Technology \\ Topi-Swabi, PAKISTAN \\ Dr. Fouzia ATLAS \\ ORCID: 0000-0002-5877-088X \\ Department of Management Sciences \\ Women University Swabi \\ Swabi, PAKISTAN \\ Sadia AKHTAR \\ ORCID: 0000-0002-6858-0617 \\ School of Humanities and Social Sciences \\ University of Science and Technology of China \\ Hefei, CHINA \\ Dr. Farhan KHAN \\ ORCID: 0000-0001-7719-7727 \\ Department of Government and Public Policy \\ National Defence University \\ Islamabad, PAKISTAN
}

Received: 26/06/2020 Accepted: 28/01/2021

\begin{abstract}
In the current digital era, Massive Open Online Courses (MOOCs) are considered as an educational revolution specifically in the current situation of COVID-19. Although students from all over the globe register for MOOCs, only a small proportion of participants complete the online courses. MOOCs at present encounter the problem of low retention rates, thus providing numerous research gaps. This paper investigates the impact of critical factors such as the instructor's role, course relevancy, learning outcomes on MOOCs retention. This study also analyzes the mediating role of IT (Social Media) between critical factors and MOOCs retention and provides feasible solutions for the improvement of MOOCs retention rates. Data were collected from Pakistani participants who attended, registered, or completed any MOOC. The findings of this study indicate that critical factors such as the instructor's role, course relevancy, learning outcomes have a positive impact on MOOC participants' retention. The results also confirm the important mediating role of IT (Social Media). The universities and the instructors who offer MOOCs should consider these critical factors when offering an online course. These critical factors can enhance MOOCs participants' retention leading them to take the courses until certification.
\end{abstract}

Keywords: Course Relevancy, COVID-19, Instructor's role, IT (Social Media), Learning Outcome, MOOCs Retention. 


\section{INTRODUCTION}

Due to rapid advancements and innovations in technologies, the need and importance of Massive Open Online Courses (MOOCs) have increased in general and in particular during the crises such as the current COVID-19 pandemic situation. With the advent of COVID-19, the world has realized the importance of rather an effective way of learning and that is why the application of MOOCs has multiplied in the current scenario (Yuan \& Powell, 2013). The online learning environment facilitates learning in higher education (Schumacher \& Ifenthaler, 2018). Students who apply their learning more effectively from online courses have a higher success factor (Sandeen, 2013). The application of MOOCs in higher education proved to be the most promising integration for the future (Johnson, et al., 2016). Although MOOCs are widely accepted, much remains to be done as the participants' overall retention rates for MOOCs are very low (Clow, 2013).

This situation requires in-depth research to determine critical factors that can help enhance the MOOCs retention rate, which is the focus of this study. For a successful MOOC program, it is important to understand the factors that motivate participants not only to register for the online course but also to complete it. Motivational factors include new skills, knowledge, the interest of the learners in the topics, career advancement, supplement to a credit-bearing course, and professional development (Zheng, Rosson, Shih, \& Caroll, 2015). These stimuli may cause someone to register for a course, but the problem arises when one fails to finish the course s/he has enrolled in (Howarth, D'Alessandro, Johnson, \& White, 2016). Failing to do so lowers the online course retention rate. Recently, 13000 students registered for MOOCs at the Coursera platform in 61 different courses. The completion rate was observed to be just above $6 \%$ showing the actual rate of MOOC retention. Although this number is increasing over time, there are still many obstacles to overcome (Onah, Sinclair, \& Boyatt, 2014). The rapid growth of MOOCs in recent years has given us the opportunity for further empirical research (Deng, Benckendorff, \& Gannaway, 2019). The purpose of this paper is to investigate the critical factors responsible for enhancing participant's MOOC retention. An increase in the completion rate can be defined as the success of the MOOC (Pursel, Zhang, Jablokow, Choi, $\&$ Velegol, 2016). For this purpose, based on extensive literature review and discussion with participants the factors we narrowed down to be studied include i.e. instructor's role, learning outcomes, and course relevancy. A survey conducted by participants from Pakistan who have taken online courses using social media interactions that help us analyze the variables particularly the mediating role of social media (IT).

\section{Purpose of the Study}

With the global spread of COVID-19, the world has realized the importance of rather an effective way of learning in the form of MOOCs due to the suspension of face-to-face classes and that is why the application of MOOCs has multiplied in the current scenario. The assimilation of MOOCs in higher education has made learning easy and effective for students and professionals. Although MOOCs have a broad application prospect, much remains to be done as the participants' overall retention rates for MOOCs are very low. The purpose of this paper is to investigate the critical factors responsible for enhancing participant's course retention in MOOC. Although previous research on MOOCs investigated the different factors for retention of courses this paper seeks to address a gap in the research by exploring the role of social media specifically in the perspective of Pakistan during COVID-19. This paper investigated the mediating role of IT (Social Media) with the instructor's role, learning outcomes, and course relevancy. Our research shows that the use of Social Media in MOOCs serves the purpose and enhances the performance of the students in terms of course retention, especially in crises like COVID-19. Our purpose and research questions lead to two research objectives: 1). How do the instructor, course relevancy, and learning outcome affect MOOCs retention? 2). How do social media facilitate course instructor interactions with MOOCs participants, sharing relevant and meaningful course materials and MOOCs retention?

\section{LITERATURE REVIEW}

Massive Open Online Courses (MOOCs) are defined as the courses available to a large number of people over the internet. MOOCs can be introduced in the sense that nowadays they are seeking a lot of attention 
as a topic for academic research (Kovanovic, Joksimovic, Gasevic, Siemens, \& Hatala, 2015). Traditional courses are mainly reduced to limited students, limited exposure, limited area, and fairly higher costs in the majority of the cases (Zhang, Huang, Lv, Liu, \& Zhou, 2018). In the same way, another obstacle to overcome in organizing traditional courses is to ensure that the number of students is sufficient to pursue a certain subject; on the contrary, the course is not offered (Virta, Hokka, Etelaplto, \& Rasku-Puttonen, 2019). In comparison, MOOCs have unlimited capacity and are considered to be the most flexible forms of education in the world since 2012 due to their easy access to everyone in the world (Sandeen, 2013). The year 2012 is called the year of MOOC (Bohnsack \& Puhl, 2014). The reason is its wider and easy platform which provides better learning opportunities (Stokes, Towers, Jinks, \& Symington, 2015). Many of the platforms are free and can be accessed at any time such as Coursera, edX (Wiley, Green, \& Soares, 2012). Based on such wide exposure, the bar of expectation of teacher and student relationship has been raised to a greater extent. Due to such exposure, the rate of registration in recent years is relatively recorded higher but those who follow the courses to completion are less ( $\mathrm{Li}$, Tang, Cao, \& Hu, 2018).

There is a lack of research to determine the reasons for the fall of many students/participants during an online course. The existing literature mainly focuses on the number of students registered for MOOCs instead of completion rates. The bioelectricity of autumn 2012 is an example of the enrolled students, i.e. more than 12,000 students who obtained the certificates or had taken the course could not even go up to one hundred (Rivard, 2013). Similarly, in another MOOC course named CCK08, more than two thousand students registered, another example of massive participation in a MOOC (McAuley, Stewart, Siemens, \& Cormier, 2010). Searching for reasons and causes of improvement in the retention of courses creates a research gap and a must investigate topic (Engle, Mankoff, \& Carbrey, 2015). Xiong, et al, (2015) concluded that students with increased inspiration, goals, and inclination to learn new skills and knowledge tend to contribute more to the completion of MOOCs. For this purpose, this research after a vigorous literature review and consultation with the participants who registered for online courses has narrowed down the most critical factors which include the instructor's role, learning outcomes, and course relevancy as well as the significant role of social media as a mediator.

\section{Instructor's Role and MOOC Participant Retention}

Instructors are responsible for integrating online resources to organize learning content, creating a highquality online learning environment that stimulates and enhance students' motivation to learn (Yount \& Tandoh, 2016). Instructors become facilitators when they encourage, lead and challenge their students by giving them freedom and awareness, rather than a traditional speaker who focuses on teaching (Huynh, 2005). An instructor provides advice and feedback to the course participants about their learning practice and achievement and it is "one of the most influential elements in the learning process" (Dick, Carey, \& Carey, 2005). The main purpose of the instructor's feedback is to enhance student performance by letting them know how well they are doing and directing them in their learning efforts. Feedback from the instructor in the web system includes the simplest cognitive response (for example, marking wrong answers in the quiz/ assignment), diagnostic feedback (for example, quiz /assignment with the instructor's explanation explaining why the answers are good or bad), normative comments (suggestions from the instructor on how the correct answers can be developed) via respondents' responses by e-mail, rated work with notes, online notebooks, synchronous and asynchronous comments. If the instructor provides appropriate and effective feedback after each course, quiz, assignment, etc., it creates a sense of belonging among the students and they are keen to complete the course (Adamopoulos, 2013). Sometimes the instructor performs the function of a facilitator in a MOOC. S/He usually provides necessary tools, skills, and materials to the students to follow and in this way, students develop a stronger connection with the instructor as well as with the course (Zheng, Han, Rosson, \& Carroll, 2016). Course participants do not know much about the subject, whether they apply it correctly in a desirable way or not, it is the feedback and the interaction with the instructor that will probably be most useful for the retention of the course. So, it can be hypothesized that.

H1: The instructor's role (feedback and interaction with students) has a positive effect on MOOC retention. 


\section{Learning Outcomes and MOOC Participant's Retention}

Learning outcomes are defined as "the learning of skills and knowledge" when a student or a professional pursues an online MOOC. There are two components of learning outcomes. The first one is "Digital literacy which is defined as the ability to use a computer, using online information while creating and managing online information" and the second is a practical implementation of secondary learning from MOOCs (which is digital skills). MOOCs retention rates significantly depend upon these two components. The learning capability of a participant is increased when s/he passes in a MOOC. Its effects are most noticeable when these skills are applied in real-life Fidal, et al, (2014). While pursuing MOOC, participants learn to access different online websites to learn and then they apply both of their learnings (MOOC specific and digital literacy) in their real life, professional career, or even in their academics (Waston, et al, 2016). MOOCs with the greater potential to teach digital skills to gain higher interest from students and thus have a higher retention rate (Viswanathan, 2012).

It can be stated that.

H2: Learning outcomes (digital skills and applications in real life) have a positive effect on MOOC participation retention.

\section{Course Relevancy and MOOC Participant Retention}

It is generally believed that online learning and online courses do not have relevant stuff in them. Relevancy of course material with the MOOC's course plays a bigger role in MOOC retention. Students and participants registering for MOOCs hope for good-quality material related to the course which is relatively easy to understand and implement. A MOOC should have rather a flexible course material that can be easily understandable for everyone alike (De, Isabella, Morgan, \& Gibson, 2015). Furthermore, for a MOOC to be successful, its course materials should possess deeper learning. In other words, the course curriculum must be in line with learning outcomes for the students to understand efficiently and develop their skills accordingly (Paton, Fluck, \& Scanlan, 2018). In this way, the participants develop interest and their motivation to pursue the MOOC until its completion increases (Breslow, Pritchard, DeBoer, \& Stump, 2013). Students participate in online courses with more willingness and motivation when course content is relevant, appealing, and comparatively of high quality (Bocchi, Eastman, \& Swift, 2004). So, it can be stated that,

H3: Course relevancy (flexible and deeper learning material) has a positive effect on MOOC retention.

\section{IT (Social Media) and MOOC Participant Retention}

Information technology is the backbone of massive open online course platforms. Access to the world through technology involves different perspectives or platforms on which social media has greater leeway. Social media can help engage MOOC students. The main reason is that majority of the young generation is attracted to social media and mostly gets their news and information based on materials available there. That is why MOOCs via social media can do wonders and help improve the overall retention rate (Ripiye, Bacon, Mackinnon, \& Walker, 2017). Researchers have found a positive relationship between social media, teaching, and learning (Manca \& Ranieri, 2017). The instructors can create official Facebook pages, Schoology, WhatsApp groups, etc. to interact with their students. The instructor can use social media websites such as YouTube, Google Drive, etc. to post and share relevant information and material and can provide feedback to the students using online blogs. In this way, students will be more attracted to MOOCs and have positive emotions towards MOOCs (Zheng, Han, Rosson, \& Carroll, 2016). This study also concludes that social media is a better place for interpersonal communication, discussion, and quick collaboration. So, it can be stated that.

H4: IT (social media) positively affects MOOC participant retention. 


\section{The Mediating Role of IT-Instructor Role and MOOC Participant Retention}

The most important impact of MOOC participant retention is the role of a teacher or instructor.

In the current pandemic (COVID-19) situation instructors provide feedback to address students' queries via social media tools such as WhatsApp groups, Microsoft Teams, ZOOM, and/or Facebooks pages and groups. Instructors can make a course boring or interesting, depending on the teaching method they follow. Assignments and relevant activities given by the instructor directly affect the motivation of the students to take a specific course. The instructor's cooperation is an important factor that influences student motivation. It simply depends on how the instructor manages relationships with his/her peers using information technology (social media). A good instructor will always strive to reach students easily and effectively (Foroughi, 2016). A good instructor with proper feedback and a discussion with students has a positive impact and vice versa (Ross, Sinclair, Knox, Bayne, \& Macleod, 2014). Inoculated with the interrelationships of the educational goals of the educator, encapsulations that represent the teacher and the relationships of the students and their personalities are what defines the role of the instructor in the retention of the MOOC (Coates, 2017). So, it can be stated as.

H5: IT (Social Media) mediates the effect of Instructors role on MOOC participation retention

\section{The Mediating Role of IT-Learning Outcomes and MOOC Participant Retention}

The effectiveness of a MOOC can be derived from the fact that it contributes a lot to the learning of students and participants. The major interest of a student enrolling in a MOOC lies in his learning outcomes as s/he aims to learn something from it. As mentioned above, the more the younger generation interacts with the IT using social media, the more they can seize the opportunity to learn and retain the course (De, Isabella, Morgan, \& Gibson, 2015). The findings of a study show that learning outcomes are dependent upon the learning specialty of a MOOC. Researchers have even suggested that the MOOC can end traditional learning and that anyone from around the world can access it online via social media (Breslow, Pritchard, DeBoer, \& Stump, 2013). Another study highlighted the importance of learning outcomes from MOOCs through various factors and concluded that by fundamental and widely approved structures, measures should be used to benchmark quality beyond global boundaries, thus ensuring that all learning objectives are achieved (De, Isabella, Morgan, \& Gibson, 2015).

Keeping in mind the points, it can be stated as.

H6: IT mediates the relationship between Learning outcomes and MOOC participants' retention.

\section{The Mediating Role of IT-Course Relevancy and MOOC Participant Retention}

The course-relevancy refers to the relevance of course content and learning materials to the academic or work-related tasks of the participants. Course relevancy significantly contributes to MOOC participant retention. While registering for a MOOC, a participant is interested in the course material that is being taught in a MOOC. For this purpose, relevant course materials within the scope of the course contributing to deeper learning can attract students. Participants' attachment to technology and easy access to course materials, tutorials, exercises, quizzes, homework, etc. can motivate them to stay till the completion of the course (Crossley, Dascalu, McNamara, Baker, \& Trausan-Matu, 2017). More than $90 \%$ of students and participants drop out because of irrelevant and insufficient content, which does not reinforce their confidence in the course (Hew, 2016). The availability of course content/material via social media and the learning of course materials by participants is important in terms of course retention (Hood, Littlejohn, \& Milligan, 2015). Based on the above-mentioned literature it can be stated as;

H7: IT (Social Media) mediates the relationship between Course relevancy and MOOC participants' retention.

Based on the above-proposed hypotheses, the main framework that is to be evaluated in this study is given in the following figure number 1 . The conceptual framework is based on the fact to evaluate the driving factors that can increase MOOC retention and enable students/personnel to continue with the MOOC until the completion stage. 


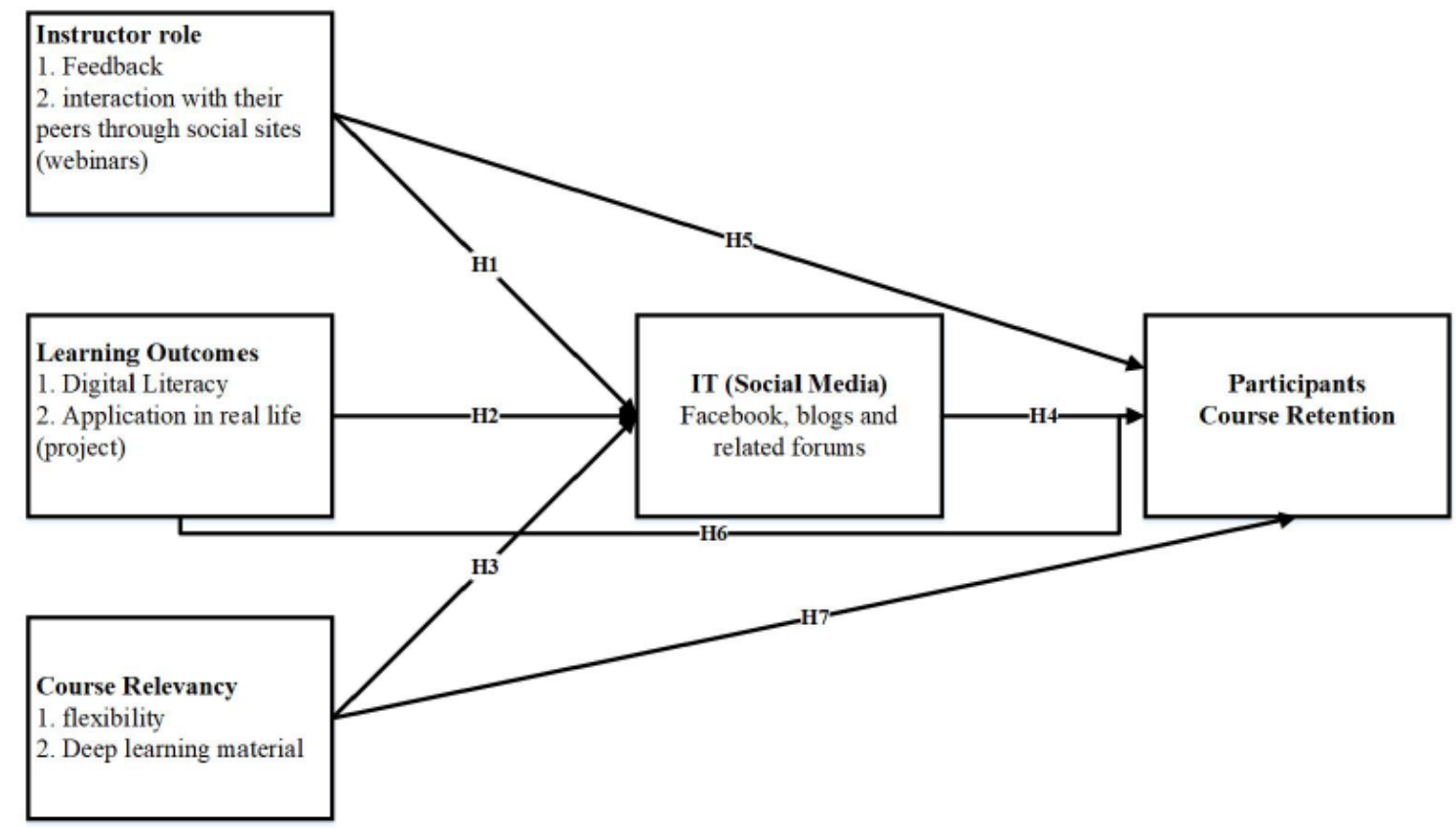

Figure 1. Conceptual Model

\section{METHODOLOGY}

\section{Participant Selection}

A well-design questionnaire was sent out to participants. Most of the participants included people who took online courses and used social media, especially Facebook and WhatsApp groups for interaction. Individuals from different industries who took online courses for their personal and technical training also participated in the survey. A questionnaire was sent out to more than 1000 participants registered on Coursera, edX, and Facebook platforms. Approximately 300 of them responded to the survey, giving an insight into the variables that may have a greater impact on MOOC retention. The questionnaire included questions related to the demographics of the participants which were kept anonymous and purely for research purposes. The demographics of the participants include their age, profession, and level of education. The second section included questions on the impact of the instructor's role on MOOC retention, i.e. the Independent variable of the research model adopted from (Viswanathan, 2012). The third section included questions based on the effect of learning outcomes on MOOC retention adopted from (Fidalgo-Blanco, Sein-Echaluce, GarciaPenalvo, \& Escano, 2014). The fourth section was based upon the course relevancy of a course being taught in MOOC adopted from (Akcaoglu \& Bowman, 2016). Lastly, the final section included questions related to the information technology (IT) as being a mediator adopted from (Wu \& Chen, 2017). MOOC retention is the dependent variable in this study and adopted from (Watted \& Barak, 2018).

\section{Data Analysis}

To explore the psychometric validity of the survey construct we used structural equation modeling (SEM). For EFA we used SPSS 25.0 and for CFA AMOS 24.0.

\section{Exploratory Factor Analysis}

In this study, we applied EFA to ensure that all the measurements items load into their respective value limits. Table1 describes the factor loading of the constructs and shows that all the items are loaded in their respective constructs. However, LO3 had multiple cross-loading in the results which have been deleted from the list. Table1 shows, Cronbach's alpha ranging from .860 to .951 and are above the benchmark value of 0.70 (Liu, Ke, Wei, \& Hua, 2013) and shows a satisfactory convergent validity of the measurements. 


\section{Confirmatory Factor Analysis}

We used AMOS 24.0 to analyze CFA for this we load all the items in a single factorindicating onedimensionality. CFA deals with the appropriate reliability measurement method for theoretical construct space (Chin \& Todd, 1995). First, we assess convergent validity (CR) and then compare the item load with the recommended minimum value of 0.60 (Chin, Gopal, \& Salisbury, 1997). Further, we assessed the average variance extracted (AVE) representing the internal consistency of the indicators measuring in the given construct (see Table1 and 2).

Table 1: Exploratory and Confirmatory Factor Analysis

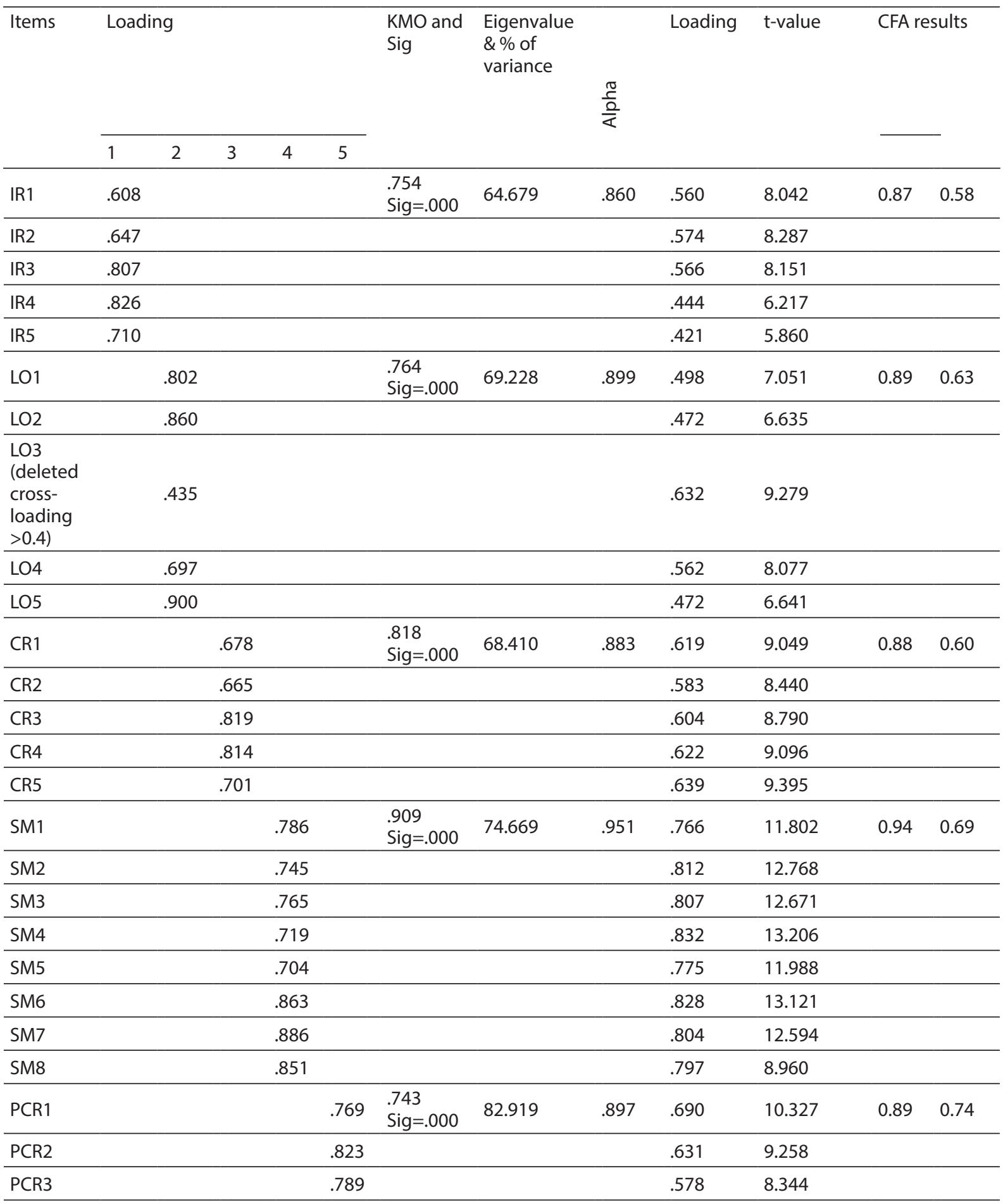


Note: LO3 deleted due to cross-loading

All estimates are significant

All estimates are above 0.4 and most above 0.7

AVE for all constructs above 0.5

CR for all constructs above 0.7

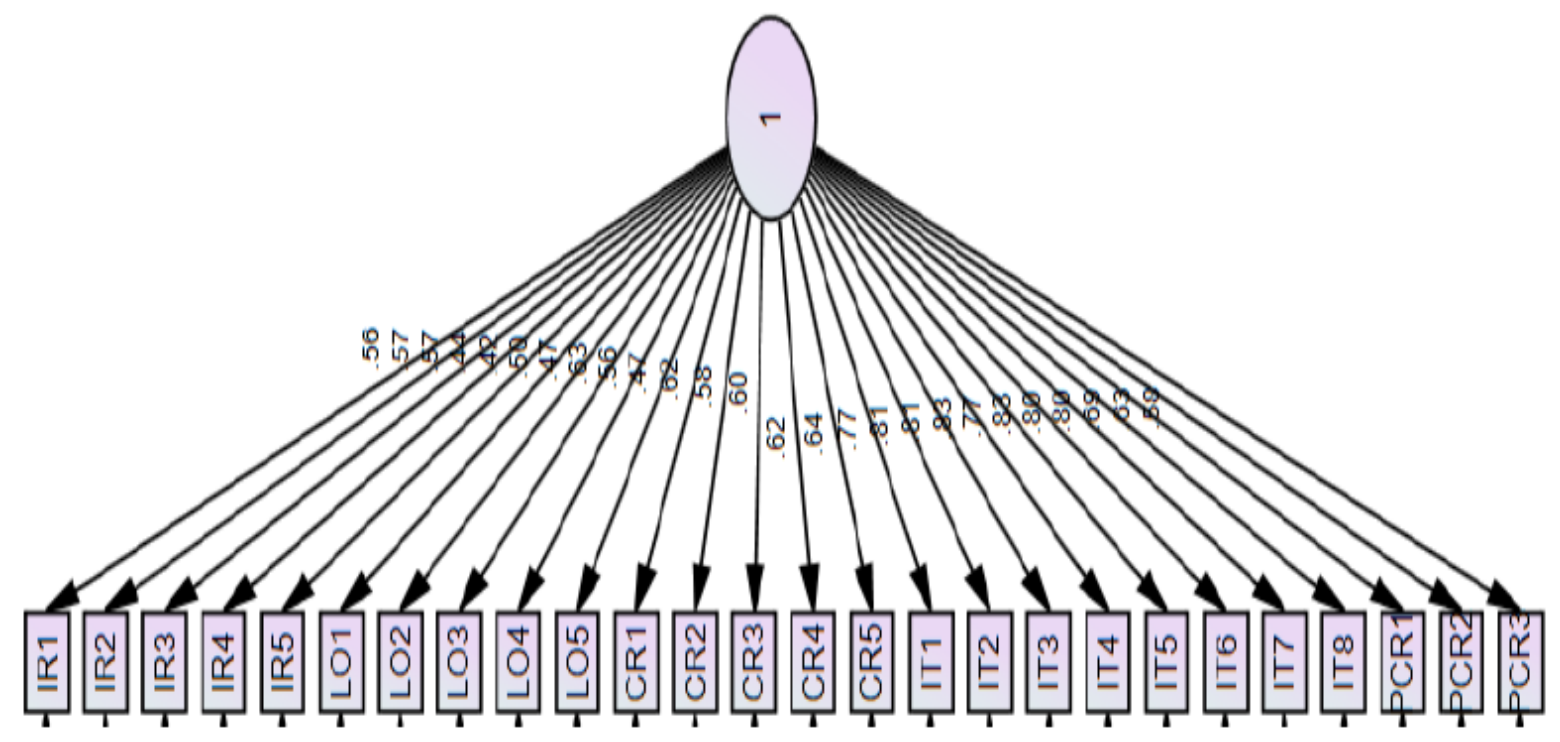

Figure 2. one construct loading

Table 2. Model Validity Measures

\begin{tabular}{cccccccc}
\hline & CR & AVE & IR & LO & CR & SM & PCR \\
\hline IP & 0.874 & 0.587 & $\mathbf{0 . 7 6 6}$ & & & & \\
LO & 0.894 & 0.636 & $0.421^{* * *}$ & $\mathbf{0 . 7 9 8}$ & & & \\
CR & 0.883 & 0.605 & $0.550^{* * *}$ & $0.410^{* * *}$ & $\mathbf{0 . 7 7 8}$ & & \\
SM & 0.948 & 0.696 & $0.456^{* * *}$ & $0.409^{* * *}$ & $0.601^{* * *}$ & $\mathbf{0 . 8 3 5}$ & \\
PCR & 0.897 & 0.745 & $0.506^{* * *}$ & $0.385^{* * *}$ & $0.561^{* * *}$ & $0.626^{* * *}$ & $\mathbf{0 . 8 6 3}$ \\
\hline${ }^{*} \mathrm{p}<0.050,{ }^{* *} \mathrm{p}<0.010,{ }^{* * *} \mathrm{p}<0.001$ & & & &
\end{tabular}

Note: No validity concerns here

Table 2 shows the multi-collinearity test by indicating all the values above the benchmark values of 0.60 . Whereas, the value of AVE is $>0.50$ (Huang, Wang, Wu, \& Wang, 2013). The rule of thumb to judge the existence of multicollinearity is if the variance inflation factor (VIF) and $>10$ or $<0.10$. Our results show that the highest VIF is 1.795 and the lowest VIF is 1.440 , thus, multi-collinearity did not seem to be a problem.

\section{Model Fit Indices and Hypothesis Testing}

Table 3 shows the overall model of fitness among the variables mentioned in the research model of the study. The results show that Chi-square normalization by the degree of freedom $(X 2 / d f)$ should be $1 \sim 3$ our results shows that $(\mathrm{X} 2 / \mathrm{df})$ is 2.170 , which is in between the benchmark. Comparative Fit Index (CFI), Incremental Fit Index (IFI), and Normed Fit Index (NFI) should be above 0.90 (Bentler, 1983). Our results indicate $0.0918,0.918$, and 0.959 respectively showing the significant values as per criteria. The goodness of Fit 
Index (FGI) should be above 0.80 the Table3 results shows a value for GFI is 0.805 , which is above the benchmark (Browne \& Cudeck, 1992). Similarly, the commonly accepted value of root means the square error of approximation (RMSEA) should be less than 0.08, for the current model RMSEA is 0.07 showing a significant value to support the model.

Table 3. Model Fit Indices of the CFA Model

\begin{tabular}{|c|c|c|c|}
\hline Index & Index value & Criteria & References \\
\hline \multicolumn{4}{|c|}{ Absolute fir measures } \\
\hline$X^{2}$ & 611.930 & & (Bagozzi, Yi, \& Nassen, 1998) \\
\hline$X^{2} /$ degree of freedom & 2.170 & Between 1 3 & \\
\hline GFI & 0.805 & $\geq 0.8$ & (Browne \& Cudeck, 1992) \\
\hline RMSEA & 0.07 & $\leq 0.08$ & \\
\hline \multicolumn{4}{|l|}{ Incremental fit measures } \\
\hline CFI & 0.918 & $\geq 0.9$ & (Joreskog \& Sorbom, 1996) \\
\hline NFI & 0.959 & $\geq 0.9$ & \\
\hline IFI & 0.918 & $\geq 0.9$ & \\
\hline \multicolumn{4}{|l|}{ Parsimonious fir measure } \\
\hline PNFI & 0.745 & $>0.50$ & (Ullman \& Bentler, 2004) \\
\hline PCFI & 0.796 & $>0.50$ & \\
\hline
\end{tabular}

\section{Hypotheses Testing}

Table 4 represents hypotheses testing. The authors predicted that the Instructor role, learning outcomes, and Course relevancy are related to social media. The results $(\beta=.456, P<0.001),(\beta=.409, P<0.001)$, and $(\beta=.601$, $\mathrm{P}<0.001$ ), show the positive relationship among these variables and support $\mathrm{H} 1, \mathrm{H} 2$, and $\mathrm{H} 3$. Moreover, the authors also predicted that IT is positively related to participants' course (MOOC) retention, for this prediction, table 4 shows that $(\beta=.626, \mathrm{P}<0.001)$ and shows a positive relationship to support the H4.

Furthermore, the study predicted that instructor role, learning outcomes, and course relevancy are positively related to participant course retention. The results $(\beta=.506, P<0.001),(\beta=.385, P<0.001)$, and $(\beta=.561$, $\mathrm{P}<0.001$ ) indicate that $\mathrm{H} 5, \mathrm{H} 6$, and $\mathrm{H} 7$ are positively supported.

Table 4. Hypothesis Testing

\begin{tabular}{lcccc}
\hline & Estimates & t-value & $P$ & Label \\
\hline F1<--->F4 (H1) & .456 & 4.623 & 0.001 & Support \\
F2<--->F4 (H2) & .409 & 4.819 & 0.001 & Support \\
F3<--->F4 (H3) & .601 & 5.958 & 0.001 & Support \\
F4<--->F5 (H4) & .626 & 6.225 & 0.001 & Support \\
F1<--->F5 (H5) & .506 & 4.801 & 0.001 & Support \\
F2<--->F5 (H6) & .385 & 4.461 & 0.001 & Support \\
F3<--->F5 (H7) & .561 & 5.537 & 0.001 & Support \\
\hline
\end{tabular}

Table 4 shows that instructor role, learning outcomes, and course relevancy have a positive influence on participant's course retention. We argue that IT (social media) has a positive mediating role between these variables. 
Table 5 shows the direct and indirect effect of instructor role on participant's course retention. The results show that IR is positively related to social media where $(\beta=.477)$. Furthermore, the tables show a positive relation between instructor role and IT $(\beta=.488)$ and finally a positive mediating role of social media by showing the total effect of $(\beta=.221)$. See figure 3

Table 5. Coefficients for the mediating effect $(\mathrm{LO} \rightarrow \mathrm{SM} \rightarrow \mathrm{PCR})$

\begin{tabular}{|c|c|c|c|c|c|}
\hline Testing paths & $\beta$ & $\operatorname{SE}(\beta)$ & $95 \% \mathrm{Cl}$ & $\beta$ & $\mathrm{Sr}^{2}$ \\
\hline \multicolumn{6}{|c|}{ Path c: DV= Participants Course Retention } \\
\hline \multicolumn{6}{|c|}{$R^{2}=.160, F(1,35,305)=, p=.000$} \\
\hline IV= Learning Outcome & .438 & .074 & $.292, .583$ & .339 & $15.92 \%$ \\
\hline \multicolumn{6}{|l|}{ Path a DV = Social media } \\
\hline \multicolumn{6}{|c|}{$R^{2}=.184, F(1,41.941)=, p=.000$} \\
\hline IV = Learning Outcome & .441 & .068 & $.307,576$ & .429 & $18.40 \%$ \\
\hline \multicolumn{6}{|c|}{ Path $b$ and $c$ DV $=$ Participants Course Retention } \\
\hline \multicolumn{6}{|c|}{$R^{2}=/ 362, F(2,52.582)=, p<0.000$} \\
\hline IV: = Learning Outcome & .203 & .071 & $.063, .344$ & .186 & $2.82 \%$ \\
\hline IV = Social Media & .532 & .069 & $.395, .668$ & .499 & $24.90 \%$ \\
\hline Total $a * b$ & & & & .214 & \\
\hline
\end{tabular}

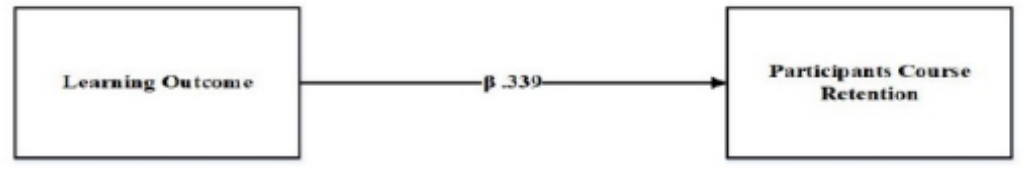

\section{Mediator in Model}

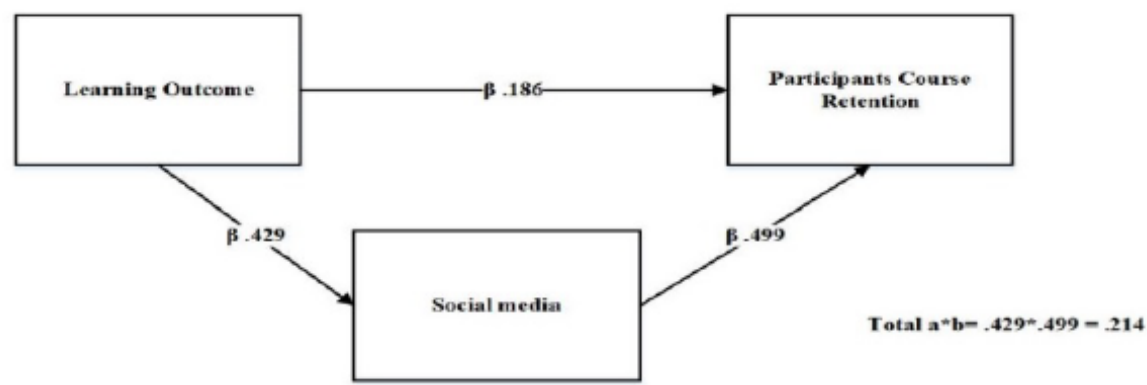

Figure 3. Model 3

Table 6 shows the direct and indirect effect of learning outcome (LO) on participant course retention (PCR). The table represents a positive direct relationship between LO and PCR $(\beta=.339)$ and a positive relationship between LO and IT (social media) $(\beta=.429)$. These results indicate the partial mediating effect of IT between LO and PCR $(\beta=.214)$ see firgure4 
Table 6. Coefficients for the mediating effect (LO $\rightarrow \mathrm{IT} \rightarrow \mathrm{PCR})$

\begin{tabular}{|c|c|c|c|c|c|}
\hline Testing paths & $\beta$ & $\operatorname{SE}(\beta)$ & $95 \% \mathrm{Cl}$ & $\beta$ & $\mathrm{Sr}^{2}$ \\
\hline \multicolumn{6}{|c|}{ Path c: DV= Participants Course Retention } \\
\hline \multicolumn{6}{|c|}{$R^{2}=.160, F(1,35,305)=, p=.000$} \\
\hline $\mathrm{IV}=$ Learning Outcome & .438 & .074 & $.292, .583$ & .339 & $15.92 \%$ \\
\hline \multicolumn{6}{|c|}{ Path a DV = IT-Social media } \\
\hline \multicolumn{6}{|c|}{$\mathrm{R}^{2}=.184, \mathrm{~F}(1,41.941)=, \mathrm{p}=.000$} \\
\hline IV = Learning Outcome & .441 & .068 & $.307,576$ & .429 & $18.40 \%$ \\
\hline \multicolumn{6}{|c|}{ Path $b$ and $c$ DV $=$ Participants Course Retention } \\
\hline \multicolumn{6}{|c|}{$R^{2}=/ 362, F(2,52.582)=, p<0.000$} \\
\hline IV: = Learning Outcome & .203 & .071 & $.063, .344$ & .186 & $2.82 \%$ \\
\hline IV = IT-Social Media & .532 & .069 & $.395, .668$ & .499 & $24.90 \%$ \\
\hline Total $a * b$ & & & & .214 & \\
\hline
\end{tabular}

\section{Mediator not in Model}

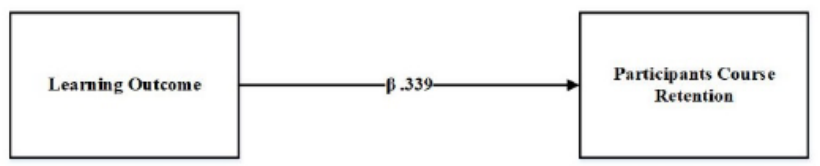

\section{Mediator in Model}

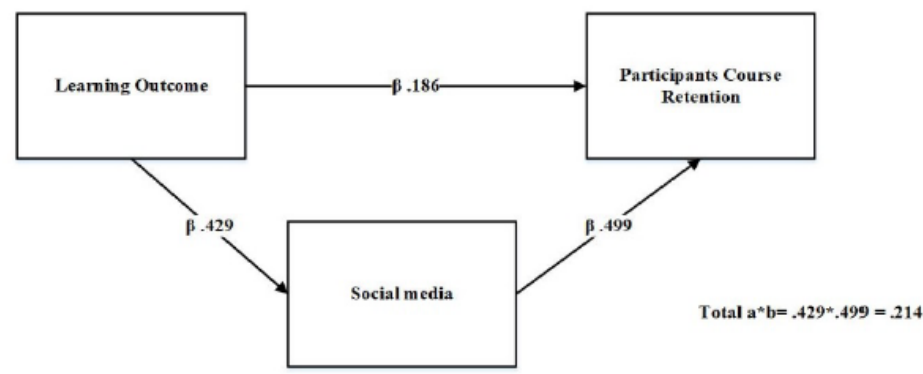

Figure 4. Model 4

Table 7 represents the relationship between course relevancy (CR) and PCR. The results indicate that CR has a positive relation with PCR $(\beta=.541)$, which indicates that IT has a partial mediating effect between CR and PCR. Moreowver, the results indicate the positive relation between CR and IT ( $\beta .594)$ and a positive partial mediating role of $S M(\beta=.235)$ see figure5 
Table 7. Coefficients for the mediating effect (CR $\rightarrow \mathrm{IT} \rightarrow \mathrm{PCR})$

\begin{tabular}{|c|c|c|c|c|c|}
\hline Testing paths & $\beta$ & $\operatorname{SE}(\beta)$ & $95 \% \mathrm{Cl}$ & $\beta$ & $\mathrm{Sr}^{2}$ \\
\hline \multicolumn{6}{|c|}{ Path c: DV= Participants Course Retention } \\
\hline \multicolumn{6}{|c|}{$R^{2}=.292, F(1,109.319)=, p=.000$} \\
\hline IV= Course Relevancy & .588 & .067 & $.456, .721$ & .541 & $29.26 \%$ \\
\hline \multicolumn{6}{|c|}{ Path a DV = IT-Social media } \\
\hline \multicolumn{6}{|c|}{$\mathrm{R}^{2}=.352, F(1,101.193)=, p=.000$} \\
\hline IV = Course Relevancy & .606 & .060 & $.487, .725$ & .594 & $35.28 \%$ \\
\hline \multicolumn{6}{|c|}{ Path $b$ and $c$ DV $=$ Participants Course Retention } \\
\hline \multicolumn{6}{|c|}{$R^{2}=.395, F(2,73.755)=, p<0.000$} \\
\hline IV: = Course Relevancy & .332 & .077 & $.179, .484$ & .305 & $9.30 \%$ \\
\hline IV = IT-Social Media & .423 & .067 & $.274, .573$ & .397 & $15.76 \%$ \\
\hline Total $a * b$ & & & & .235 & \\
\hline
\end{tabular}

\section{Mediator not in Model}

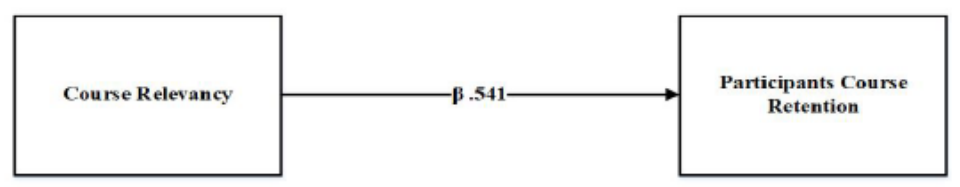

\section{Mediator in Model}

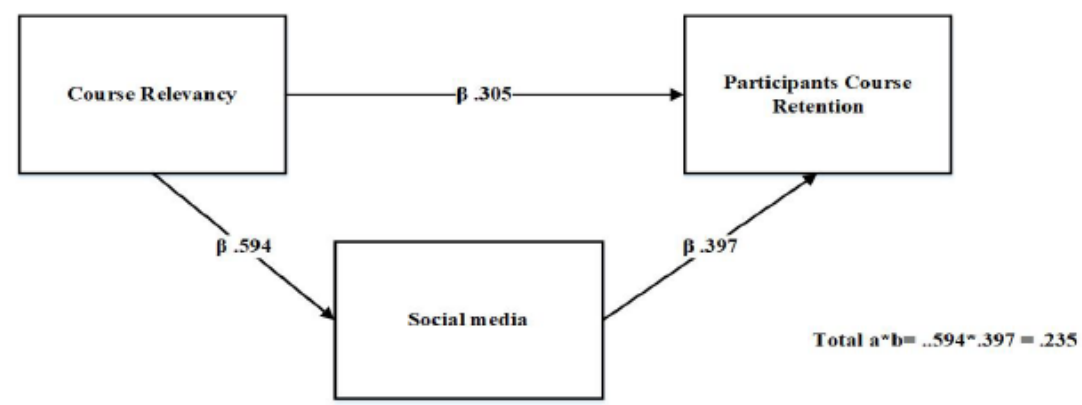

Figure 5. Model 5

Finally, Figure 6 shows the Total, Direct and indirect effects. We used SPSS to analyze the mediating effect of SM between IR, LO, CR, and PCR. We followed Andrew F. Hayes Process, which is used for estimating direct and indirect effects in single and multiple mediator models. We followed the $95 \%$ confidence intervals. The results in models 1, 2, and 3 show the positive total, direct, and indirect effect of IR, LO, and CR on PCR by mediating through IT-Social Media. These results further clarify the positive partial mediating effect of IT-Social Media. 


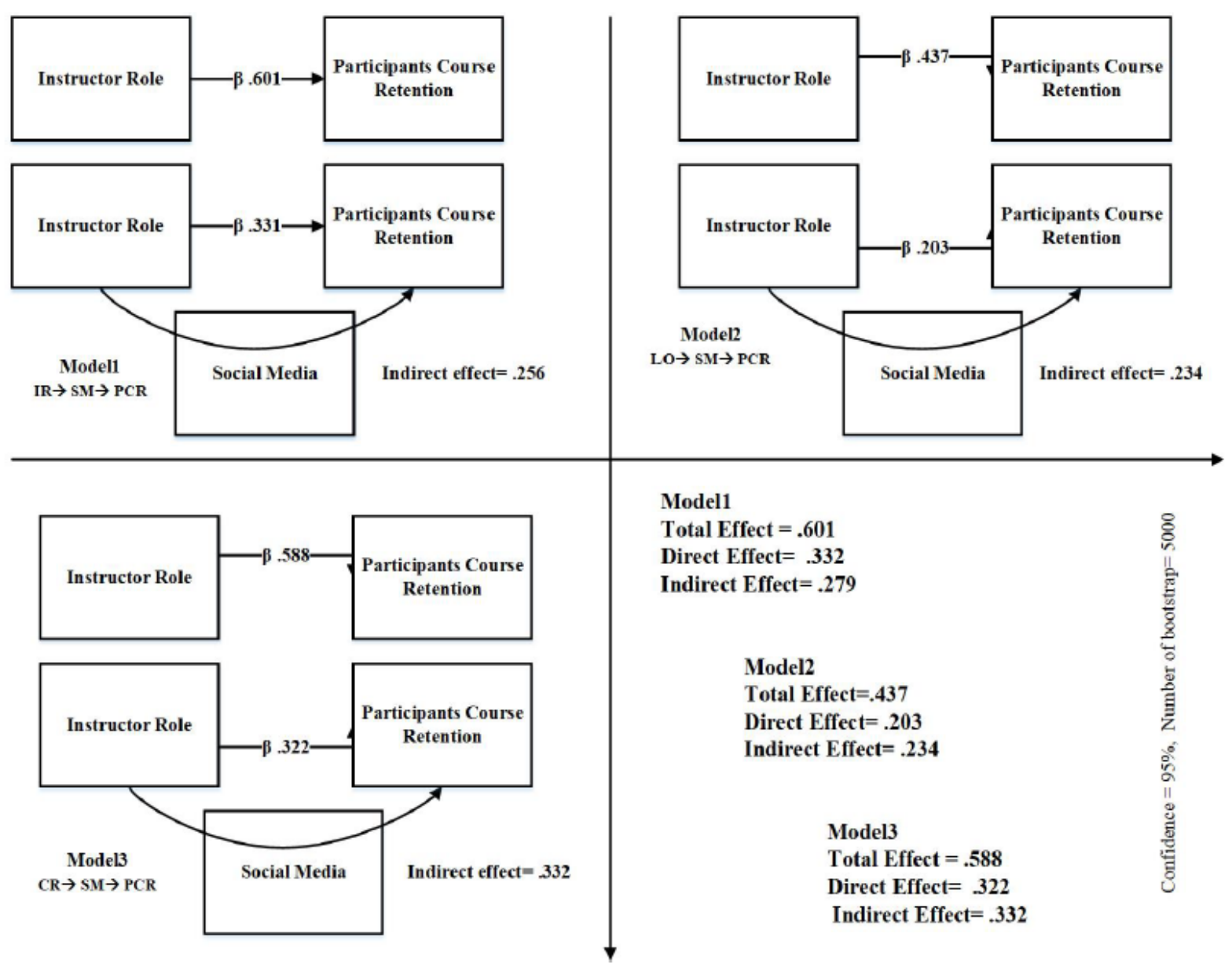

Figure 6. Total, Direct, and Indirect Effect

\section{DISCUSSION}

This research study aimed to investigate critical factors responsible for the participant's MOOCs retention. The key factors responsible for this phenomenon include i.e. the instructor role, learning outcomes, course relevancy, and IT (Social Media). In this paper, we proposed a conceptual model which we empirically tested for its validation by data collected from respondents (university students and professionals). The results of the survey provided strong empirical support for all the proposed hypothesized relationships between the constructs. Figure 2 to Figure 6 highlight these significant relationships. The findings of this research are supported by and confirm those found in the existing literature such as (Hone \& Said, 2016), (Babori, Fassi, $\&$ Zaid, 2019) and (Petronzi \& Hadi, 2016) and show that a competent and cooperative instructor plays an important role in establishing a trusting relationship between both parties (Fouzia, 2018) and helping students learn new things or gain knowledge. Such sort of interaction with the instructor enhances MOOC retention. Institutions' strategic competitiveness depends on their strategic resources and capabilities which include human resources (Khan, 2020) such as competent and interactive instructors for a MOOC course. Higher educational institutions need the best leaders (instructors) and a collaborative atmosphere to motivate students for learning and to achieve fruitful academic outcomes in a competitive global environment (Akhtar, 2019). MOOCs Participants reported that they felt isolated and described being demotivated to continue because of low interaction, poor feedback, and communication with instructors.

Furthermore, poor communication and the lack of timely and clear feedback through social media platforms from the instructor can contribute to the participant's feelings of frustration. In their study (Baturay \& Yukselturk, 2015) said that 35\% of students reported their dissatisfaction because of the lack of interaction with the instructor. 
For example:

"I did not continue with the Coursera course as I was demotivated due to poor instructor's feedback"

"The instructor did not praise learners"

"The instructor didn't engage us in discussions"

The second important variable discussed is learning outcomes, concerned with whether the participants can operate digital literacy (online learning) or not? And whether they can apply the knowledge gained through MOOCs in their real life? The answer to these questions probably is yes; students with higher knowledge of digital literacy are more likely to be successful in MOOC (online courses) and will have more intentions to apply all the knowledge practically. Existing literature such as (Tang \& Chaw, 2016), (Prior, Mazanov, Meacheam, Heaslip, \& Hanson, 2016), and (Hallaq, 2016) support these arguments highlighting the significant role that digital literacy plays in MOOC retention. Course relevancy is primarily concerned with whether students learn anything deeper in detail and the clarity of the contents being taught to the students. MOOC is an easy way for students to achieve their targets and learn new things quickly, but the question is how relevant is the course? Irrelevant course materials lead to increased participants' dropouts. So, course relevancy has a positive effect on MOOC Learning and retention. Participants are excited about the course projects which they think will help to address real-life problems in their way. Relevant, related, and updated course contents such as textbooks, lecture materials, instructor's feedback via social media would enhance participants' knowledge and skills which in turn would improve their professional work, enhance job performance or promote their advancement in the workplace. Consequently, they would be encouraged to complete the course otherwise they leave it (Belanger and Thornton, 2013). Some common comments regarding course components of MOOCs include "the professor is a great teacher", "the assignments were hard, but the lecture material was excellent and easy to follow". That positive effect of course relevancy on MOOCs retention is also highlighted in existing literature such as (Greene, Oswald, \& Pomerantz, 2015), (Baturay \& Yukselturk, 2015), and (van, Williams, \& Zirkle, 2016).

One of the important contributions of this paper includes the mediating role of social media. Social networking tools (Google, Facebook, WhatsApp, and Blogs, etc.) have become one of the strengths of effective MOOCs as they enhance informal interactions, exchange of ideas, and promote personal learning networks that have a significant impact on participants' formal learning outcomes. However, less research is available on in-depth analysis of social media usage, the relationship of usage between a MOOC platform and social media, and the rationales of the usages from both instructors' and students' perspectives. This research is an endeavor to provide design principles for successful MOOCs platforms in the future and help teachers and participants make better use of social media to improve participants' retention. Instructors use social media as an alternative channel to communicate with and provide timely and quick feedback to the participants. Research has shown that appropriate use of the social media tool could help engage students and improve their retention during the course (Baturay \& Yukselturk, 2015; van, Williams, \& Zirkle, 2016). Instructor using Google, Facebook, or WhatsApp groups to post announcements, promote course discussion, or share additional resources with MOOCs participants who can contribute to the discussion and share new resources. The results of this study also supported hypotheses regarding the mediating role of social media and confirm the same facts found by prior studies e.g. (Kaplan \& Haenlein, 2016), (TovenLindsey, Rhoads, \& Lozano, 2015), (Joksimovic, Gasevic, Kovanovic, Riecke, \& Hatala, 2015). Existing literature (Lau \& Roeser, 2002) also emphasizes that monitoring students' activities online and encouraging them through timely feedback and interaction will more likely increase MOOCs retention. (Koller, $\mathrm{Ng}$, Do, \& Chen, 2013) also posit that in the absence of social media interactions, instructor's feedback, and availability of relevant and easy to access course materials only $25 \%$ of the participants are expected to complete their online courses.

\section{CONCLUSION}

MOOCs yield great individual and collective social benefits, as they offer the mode of instruction that overcomes several of the traditional obstacles in education, such as academic background and financial costs. Massive Open Online Courses (MOOCs) are one of the revolutions and experienced rapid development in 
education history. However, the low retention rate has become a major issue. The purpose of this research was to investigate the factors responsible for the improvement of MOOCs retention rates. After a rigorous literature review, the factors examined in this research include instructor role, course relevance, and learning outcomes. We also examined the mediating effect of social media between all the critical factors listed above and MOOC's retention. The findings of this research identified a significant positive effect of instructor feedback and interaction with students on MOOCs retention. Previous research studies, while, analyzing the impact of MOOC design features on dropout rate, found, amongst other results, that the interaction with the instructor had a substantial effect on the students' completion and continuation of the course (Charo, 2020), our results are consistent with the previous research. We also found a positive and significant impact of participants' digital literacy, flexible, related, relevant, and readily available course contents which they think will stent with the previous research have an impact on their job performance and professional learning on participants' MOOCs retention. Finally, we found that participants showed higher engagement and retention using social media tools such as WhatsApp or Facebook groups. Participants found these social media tools more convenient and better place for collaboration and interaction with course instructors and colleagues. Using social networking tools helps in cultivating a sense of community, creativity and enhancing students' retention.

This research effectively extends the findings of prior researchers. Generally, most of the researches conducted on MOOCs is based on the quantitative approach and they are only directed towards students. In the future, researchers can either opt for qualitative approaches or can actively target MOOCs designers, developers, and instructors to enhance the understanding of MOOCs. By doing so, researchers will be able to provide further novelty in this topic. In the current COVID-19 pandemic situation due to a halt in traditional classes, researchers can further investigate the role of organizational support in terms of IT, students' motivation, and perceived ease of using the online platforms offering MOOCs in developing economies.

\section{BIODATA and CONTACT ADDRESSES of AUTHORS}

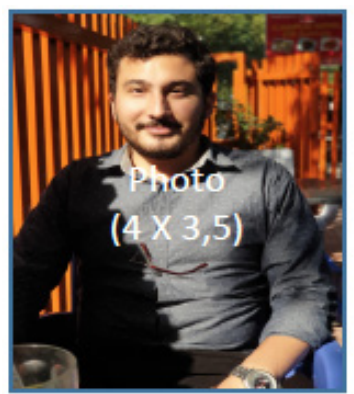

Amin Ullah KHAN is a doctoral candidate in the Department of Economics and Law at the University of Macerata, Italy. He has completed his Engineering in Photonics specialization and has a Master's degree in Engineering Management from GIK Institute, Pakistan. He is currently pursuing his Ph.D. in Management and Economics (Quantitative Methods for Policy Evaluation) from the University of Macerata, Italy. His research areas include Operations Management, Supply Chain Management, Sustainability, Input-Output and Computational General Equilibrium Models. He has currently 13 publications in the journals of internationally reputed indexations and a cumulative Impact Factor of 21.46.

Amin Ullah KHAN

Department of Economics and Law

Address: University of Macerata, 62100, Macerata, Italy

Phone: $+393206280378,+923446517738$

E-mail: amin.llh@gmail.com, a.ullah1@unimc.it

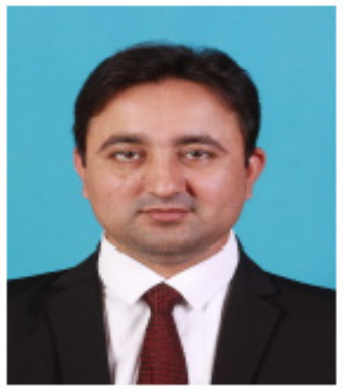

Kashif Ullah KHAN is assistant professor at School of Management Sciences, GIK Institute, Topi Swabi. He has completed PhD degree in 2017 from University of Science and Technology of China. His research interests include but not limited to SMEs, Intangible Resources such as Dynamic managerial capabilities, Dominant logic and human capital, Strategic Management. He published eleven research articles as a co-author in various international and journals. He has published several research articles both as an author and coauthor in internationally renowned peer reviewed journals. 


\section{Kashif Ullah KHAN}

School of Management Sciences

Address: Ghulam Ishaq Khan Institute of Engineering Sciences and Technology,

23340, Topi-Swabi, Pakistan

Phone: +923315998532

E-mail: kashifullah@giki.edu.pk

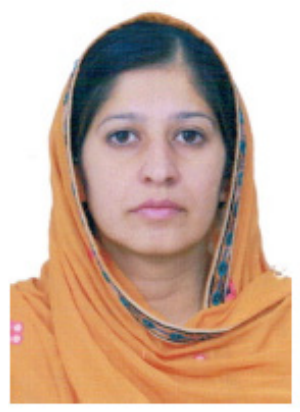

Dr.Fouzia ATLAS is serving as Assistant Professor, Department of Management Sciences, Women University Swabi, Pakistan. She completed her Ph.D. in 2017 from University of Science and Technology of China. Her academic interest areas are Trust violations and trust repair issues in organizations, SMEs in Transition Economies, innovation, IT capabilities and Online Education. She published 11 articles as a co-author in international journals and presented papers in wellknown international conferences i.e., European academy of Management and British academy of management.

\section{Fouzia ATLAS}

Department of Management Sciences

Address: Women University Swabi, Pakistan

Phone: +92 3365842524,

E-mail: fauzkashif@gmail.com

Sadia AKHTAR is a Ph.D. student at the University of Science and Technology of China (USTC). She received her Master's from the USTC in 2019. Her research focuses on technology adoption (i.e. social media and mobile technologies), consumer behavior, leadership, cross-cultural differences, social entrepreneurship, and environmental sustainability in educational organizations. She has published more than 20 publications in peer-reviewed international journals including 3 international conference papers.

\section{Sadia AKHTAR}

School of Humanities and Social Sciences, USTC

Address: University of Science and Technology of China, 230026, Hefei China

Phone: +86-13023060215

Email: sadia@mail.ustc.edu.cn

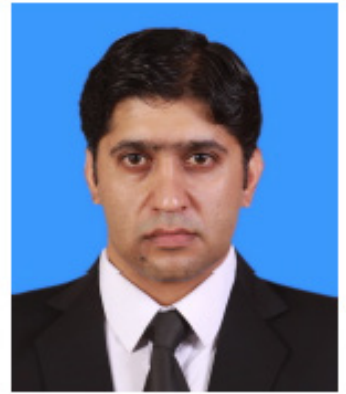

Dr.Farhan KHAN is an Assistant Professor of Faculty of Contemporary studies at National Defence University. Dr. Khan gained his Ph.D. in Public Administration in July 2017. His academic interest areas are knowledge management, performance management, social media, innovation performance, IT capabilities, public sector knowledge sharing and use of social media. He has a number of journal articles published in international indexes and papers presented in well-known international conferences i.e., European academy of Management and British academy of management.

\section{Farhan KHAN}

Department of Government and Public Policy

Address: National Defence University, 44000, Islamabad, Pakistan

Phone: +92 051-9262055-8232,

E-mail: farhankhan7727@yahoo.com; farhan@ndu.edu.pk 


\section{REFERENCES:}

Adamopoulos, P. (2013). What makes a great MOOC? An interdisciplinary analysis of student retention in online courses. 34th International Conference on Information Systems (ICIS). Milano.

Akcaoglu, M., \& Bowman, N. D. (2016). Using instructor-led Facebook groups to enhance students' perceptions of course content. Computers in Human Behavior, 65(1), 582-590.

Babori, A., Fassi, H. F., \& Zaid, A. (2019). Research on MOOCs: current trends and taking into account of content. Proceedings of the 2nd International Conference on Networking, Information Systems \& Security. Rabat.

Bagozzi, R. P., Yi, Y., \& Nassen, K. D. (1998). Representation of measurement error in marketing variables: Review of approaches and extension to three-facet designs. Journal of Econometrics, 89(1-2), 393421.

Baturay, M., \& Yukselturk, E. (2015). The Role of Online Education Preferences on Student's Achievement. Turkish Online Journal of Distance Education, 16(3), 3-12.

Bentler, P. M. (1983). Some contributions to efficient statistics in structural models: Specification and estimation of moment structures. Psychometrika, 48(4), 493-517.

Bocchi, J., Eastman, J. K., \& Swift, C. O. (2004). Retaining the online learner: Profile of students in an online MBA program and implications for teaching them. Journal of education for Business, 79(4), 245-253.

Bohnsack, M., \& Puhl, S. (2014). Accessibility of MOOCs. International Conference on Computers for Handicapped Persons. Linz.

Breslow, L., Pritchard, D. E., DeBoer, J., \& Stump, G. S. (2013). Studying learning in the worldwide classroom research into edX's first MOOC. Research \& Practice in Assessment, 8(1), 13-25.

Browne, M. W., \& Cudeck, R. (1992). Alternative ways of assessing model fit. Sociological methods \& research, 21(2), 230-258.

Chin, W. W., \& Todd, P. A. (1995). On the use, usefulness, and ease of use of structural equation modeling in MIS research: a note of caution. MIS Quarterly, 19(2), 237-246.

Chin, W. W., Gopal, A., \& Salisbury, W. D. (1997). Advancing the theory of adaptive structuration: The development of a scale to measure faithfulness of appropriation. Information systems research, 8(4), 342-367.

Clow, D. (2013). MOOCs and the funnel of participation. Proceedings of the third international conference on learning analytics and knowledge. New York.

Coates, H. (2017). The market for learning. Singapore: Springer.

Crossley, S., Dascalu, M., McNamara, D. S., Baker, R., \& Trausan-Matu, S. (2017). Predicting success in massive open online courses (MOOCS) using cohesion network analysis. PA: International Society of the Learning Sciences, Philadelphia.

De, F., Isabella, S., Morgan, J., \& Gibson, D. (2015). Will MOOCs transform learning and teaching in higher education? Engagement and course retention in online learning provision. British Journal of Educational Technology, 46(3), 455-471.

Deng, R., Benckendorff, P., \& Gannaway, D. (2019). Learner engagement in MOOCs: Scale development and validation. British Journal of Educational Technology, 0(0), 1-18.

Dick, W., Carey, L., \& Carey, J. O. (2005). The systematic design of instruction. Florida: Florida state university.

Engle, D., Mankoff, C., \& Carbrey, J. (2015). Coursera's introductory human physiology course: Factors that characterize successful completion of a MOOC. International Review of Research in Open and Distributed Learning, 16(2), 46-68. 
Fidalgo-Blanco, A., Sein-Echaluce, M. L., \& Garcia-Penalvo, F. J. (2014). Improving the MOOC learning outcomes throughout informal learning activities. Proceedings of the second international conference on Technological Ecosystems for Enhancing Multiculturality. Salamanca.

Fidalgo-Blanco, A., Sein-Echaluce, M. L., Garcia-Penalvo, F. J., \& Escano, J. E. (2014). Improving the MOOC learning outcomes throughout informal learning activities. Proceedings of the second international conference on Technological Ecosystems for Enhancing Multiculturality. New York.

Foroughi, A. (2016). MOOCs: The Enduring Importance of” Teacher Presence". Journal of Higher Education Theory and Practice, 16(6), 76.

Hallaq, T. (2016). Evaluating online media literacy in higher education: validity and reliability of the Digital Online Media Literacy Assessment (DOMLA). Journal of Media Literacy Education, 8(1), 62-84.

Hew, K. F. (2016). Promoting engagement in online courses: What strategies can we learn from three highly rated MOOCS. British Journal of Educational Technology, 47(2), 320-341.

Hone, K. S., \& Said, R. G. (2016). Exploring the factors affecting MOOC retention: A survey study. Computers \& Education, 98(1), 157-168.

Hood, N., Littlejohn, A., \& Milligan, C. (2015). Context counts: How learners' contexts influence learning in a MOOC. Computers \& Education, 91(1), 83-91.

Howarth, J. P., D’Alessandro, S., Johnson, L., \& White, L. (2016). Learner motivation for MOOC registration and the role of MOOCs as a university 'taster'. International Journal of Lifelong Education, 35(1), 74-85.

Huang, C.-C., Wang, Y.-M., Wu, T.-W., \& Wang, P.-A. (2013). An empirical analysis of the antecedents and performance consequences of using the moodle platform. International Journal of Information and Education Technology, 3(2), 217-221.

Huynh, M. Q. (2005). Viewing e-learning productivity from the perspective of Habermas' cognitive interests theory. Journal of Electronic Commerce in Organizations, 3(2), 33-45.

Johnson, L., Becker, S. A., Cummins, M., Estrada, V., Freeman, A., \& Hall, C. (2016). NMC horizon report: 2016 higher education edition. Texas: The New Media Consortium.

Joksimovic, S., Gasevic, D., Kovanovic, V., Riecke, B. E., \& Hatala, M. (2015). Social presence in online discussions as a process predictor of academic performance. Journal of Computer Assisted Learning, 31(6), 638-654.

Joreskog, K. G., \& Sorbom, D. (1996). LISREL 8: User's reference guide. Illinois: Scientific Software International.

Kaplan, A. M., \& Haenlein, M. (2016). Higher education and the digital revolution: About MOOCs, SPOCs, social media, and the Cookie Monster. Business Horizons, 59(4), 441-450.

Koller, D., Ng, A., Do, C., \& Chen, Z. (2013). Retention and intention in massive open online courses: In-depth. Educause review, 48(3), 62-63.

Kovanovic, V., Joksimovic, S., Gasevic, D., Siemens, G., \& Hatala, M. (2015). What public media reveals about MOOC s: A systematic analysis of news reports. British Journal of Educational Technology, 46(3), 510-527.

Lau, S., \& Roeser, R. W. (2002). Cognitive abilities and motivational processes in high school students' situational engagement and achievement in science. Educational Assessment, 8(2), 139-162.

Li, J., Tang, Y., Cao, M., \& Hu, X. (2018). The moderating effects of discipline on the relationship between asynchronous discussion and satisfaction with MOOCs. Journal of Computers in Education, 5(3), 279-296.

Liu, H., Ke, W., Wei, K. K., \& Hua, Z. (2013). The impact of IT capabilities on firm performance: The mediating roles of absorptive capacity and supply chain agility. Decision support systems, 54(3), 1452-1462. 
Manca, S., \& Ranieri, M. (2017). Implications of social network sites for teaching and learning. Where we are and where we want to go. Education and Information Technologies, 22(2), 605-622.

Onah, D. F., Sinclair, J., \& Boyatt, R. (2014). Dropout rates of massive open online courses: behavioural patterns. EDULEARN14 proceedings. Barcelona.

Paton, R. M., Fluck, A. E., \& Scanlan, J. D. (2018). Engagement and retention in VET MOOCs and online courses: A systematic review of literature from 2013 to 2017. Computers \& Education, 125(1), 191-201.

Petronzi, D., \& Hadi, M. (2016). Exploring the factors associated with MOOC engagement, retention and the wider benefits for learners. European Journal of Open, Distance and E-learning, 19(2), 112-129.

Prior, D. D., Mazanov, J., Meacheam, D., Heaslip, G., \& Hanson, J. (2016). Attitude, digital literacy and self efficacy: Flow-on effects for online learning behavior. The Internet and Higher Education, 29(1), 91-97.

Pursel, B. K., Zhang, L., Jablokow, K. W., Choi, G. W., \& Velegol, D. (2016). Understanding MOOC students: motivations and behaviours indicative of MOOC completion. Journal of Computer Assisted Learning, 32(3), 202-217.

Ripiye, P.-R., Bacon, L., Mackinnon, L., \& Walker, S. (2017). The use of social media in MOOCs: A review of literature. ECSM 2017 4th European Conference on Social Media. Vilnius.

Rivard, R. (2013, March 8). Inside higher ED. Retrieved January 29, 2020, from Inside higher ED: https:// www.insidehighered.com/news/2013/03/08/researchers-explore-who-taking-moocs-and-why-somany-drop-out

Ross, J., Sinclair, C., Knox, J., Bayne, S., \& Macleod, H. (2014). Teacher experiences and academic identity: The missing components of MOOC pedagogy. MERLOT Journal of Online Learning and Teaching, 10(1), 57-69.

Sandeen, C. (2013). Assessment's Place in the New MOOC World. Research \& practice in assessment, 8(1), 5-12.

Sandeen, C. (2013). Integrating MOOCs into traditional higher education: The emerging "MOOC 3.0" era. Change: The magazine of higher learning, 45(6), 34-39.

Schumacher, C., \& Ifenthaler, D. (2018). Features students really expect from learning analytics. Computers in Human Behavior, 78(1), 397-407.

Stokes, C. W., Towers, A. C., Jinks, P. V., \& Symington, A. (2015). Discover Dentistry: encouraging wider participation in dentistry using a massive open online course (MOOC). British Dental Journal, 219(2), 81-85.

Tang, C. M., \& Chaw, L. Y. (2016). Digital Literacy: A Prerequisite for Effective Learning in a Blended Learning Environment? Electronic Journal of E-learning, 14(1), 54-65.

Toven-Lindsey, B., Rhoads, R. A., \& Lozano, J. B. (2015). Virtually unlimited classrooms: Pedagogical practices in massive open online courses. The internet and higher education, 24(1), 1-12.

Ullman, J. B., \& Bentler, P. M. (2004). Structural equation modeling: Handbook of Data Analysis. California: SAGE publishing.

van, R., Williams, S., \& Zirkle, K. (2016). Balancing pedagogy, student readiness and accessibility: A case study in collaborative online course development. The Internet and Higher Education, 28(1), 1-7.

Virta, J., Hokka, P., Etelaplto, A., \& Rasku-Puttonen, H. (2019). Professional identity among student teachers of physical education: the role of physicality. European Journal of Teacher Education, 42(2), 192-210.

Viswanathan, R. (2012). Teaching and Learning through MOOC. Frontiers of Language and Teaching, 3(1), 32-40.

Viswanathan, R. (2012). Teaching and Learning through MOOC. Frontiers of Language and Teaching, 3(1), $32-40$. 
Wastson, S. L., Loizzo, J., Watson, W. R., Mueller, C., \& Lim, J. (2016). Instructional design, facilitation, and perceived learning outcomes: An exploratory case study of a human trafficking MOOC for attitudinal change. Educational Technology Research and Development, 64(6), 1273-1300.

Watted, A., \& Barak, M. (2018). Motivating factors of MOOC completers: Comparing between universityaffiliated students and general participants. The Internet and Higher Education, 37(1), 11-2-.

Watted, A., \& Barak, M. (2018). Motivating factors of MOOC completers: Comparing between universityaffiliated students and general participants. The Internet and Higher Education, 37(1), 11-20.

Wiley, D., Green, C., \& Soares, L. (2012). Dramatically Bringing down the Cost of Education with OER: How Open Education Resources Unlock the Door to Free Learning. Center for American Progress, Washington.

Wu, B., \& Chen, X. (2017). Continuance intention to use MOOCs: Integrating the technology acceptance model (TAM) and task technology fit (TTF) model. Computers in Human Behavior, 67(1), 221232.

Xiong, Y., Li, H., Kornhaber, M. L., Suen, H. K., Pursel, B., \& Goin, D. D. (2015). Examining the relations among student motivation, engagement, and retention in a MOOC: A structural equation modeling approach. Global Education Review, 2(3), 23-33.

Yount, A., \& Tandoh, K. (2016). Teaching and Learning Online: An Examination of Effective Techniques, Practices, and Processes. IGI Global, Muncie.

Yuan, L., \& Powell, S. J. (2013). MOOCs and open education: Implications for higher education. The University of Bolton, Bolton.

Zhang, H., Huang, T., Lv, Z., Liu, S., \& Zhou, Z. (2018). MCRS: A course recommendation system for MOOCs. Multimedia Tools and Applications, 77(6), 7051-7069.

Zheng, S., Han, K., Rosson, M. B., \& Carroll, J. M. (2016). The role of social media in MOOCs: How to use social media to enhance student retention. Proceedings of the Third (2016) ACM Conference on Learning@Scale. Edinburgh.

Zheng, S., Rosson, M. B., Shih, P. C., \& Caroll, J. M. (2015). Understanding student motivation, behaviors and perceptions in MOOCs. Proceedings of the 18th ACM conference on computer supported cooperative work \& social computing. New York. 